\title{
Effects of Peer Education on Attitudes of Secondary School Students Towards the Course of Physical Education and Sports
}

\author{
Mustafa Karadağ ${ }^{1}$, Resul Ağirtaş ${ }^{1}$, Atilla Pulur ${ }^{1}$ \\ ${ }^{1}$ Firat University Faculty of Sports Science ${ }^{1}$ Gazi University Faculty of Sports Science, Turkey \\ Correspondence: Mustafa Karadağ, Sports Science Faculty, Firat University, Turkey.
}

Received: April 9, 2018

Accepted: May 8, 2018 Online Published: May 25, 2018

doi:10.11114/jets.v6i4a.3171

URL: https://doi.org/10.11114/jets.v6i4a.3171

\begin{abstract}
The purpose of this study is to determine the changes in student attitudes towards the course of Physical Education and Sports as well as in students' development of skill as a result of using Peer Education in the course of Physical Education and Sports in secondary schools.

The study was conducted with a total of 120 students, who studied in the 7th grade at Atatürk Secondary School located in the Province of Elazı $\breve{g}$, District of Maden and at Cumhuriyet Secondary School located in the District of Sivrice, in the second term of 2015-2016 school year. The students in the sample group were divided into two 30-person groups, namely the control group and the experimental group. For heterogeneous selection of the students, the student selection was conducted by applying the Peer Educator Observation Form and the "Who is this?" Test in the classroom. The process was explained to the designated peer educators and their voluntary consent forms were obtained. "The Course of Physical Education Attitude Scale" was applied to all students before starting the process. After providing the students comprising the experimental group with the necessary information about peer education, the lessons were taught through the method of peer education. And in the control group, the course of physical education and sports was conducted through the traditional teaching methods. At the end of 4 weeks of application, "The Course of Physical Education Attitude Scale" was reapplied to both the experimental group and the control group.

The attitude scale was applied twice, before and after the education. The qualitative data were obtained from the diaries of the physical education teachers and students. In the analysis of the data, for qualitative dimension, descriptive analysis, for quantitative data, $\%$, frequency, for repetitive measurements, $t$ test and one-way variance analysis were used. The SPSS (22) package program was used for the analysis of the quantitative data. The quantitative data were explained through tabulation. Again, the data obtained from observation forms were presented in the form of tables with their frequency and percentage values. Themes were obtained by coding the qualitative data.

At the end of the research, the education received by the students in the experimental and control groups led to a significant difference in pre- and post-program attitude level in favor of the end-test. However, it was determined that being in different groups did not lead to a significant difference in students' attitude scores.
\end{abstract}

Keywords: physical education and sports, peer education, attitude scale

\section{Introduction}

The concept of education occupies a quite prominent place at the present time when the value of knowledge constantly increases. The changes in recent years such as the dizzying development of technology, the changes seen in economic, political and social areas, and the increase of the dissemination channels of information have brought the education to a more strategic position in human life. The purpose of the education is to transfer the knowledge, skills, values and rules that are necessary for future generations to adapt to social life (Çolakoğlu, 2004). Education is a continuous activity that starts from birth and continues until death. From the moment of birth, humans live in a physical environment where other animate and inanimate creatures exist. People need to adapt to the environment they live in so that they can continue their lives. The mankind interacts with the environment they live in and form various behaviors, values and rules by which they can adapt to this environment (Kangalgil and Dönmez, 2003).

Physical education and sports within the process of education has the purpose that the students reach targets such as physical and mental development, compliance with individuals and societies around, adapting to social rules, 
self-awareness, being able to well determine their expectations and objectives, having sense of responsibility; understanding, comprehending, and internalizing national emotions; and self-fulfillment throughout life. Countries show differences in terms of the course of physical education and sports curricula within the education process according to their development levels. Today, in the modern education system, students are supported in academic and social aspects through physical education and sports. This understanding argues that the gains and learning attained by individuals in the course of physical education and sports need to be maintained after the education process (Aybek, 2007).

Physical education, which includes activities such as game, competition, physical activities, exercise and sports activities, educates people through physical activities. We may define physical education as an educational tool that endeavors to realize, through the help of physical activities and exercises, physical, mental and spiritual development of individuals, balanced development of individuals in every aspect, and their being useful for the society they live in (Açak, 2005).

Physical education and sports have a very important role in people's physical, mental and spiritual development as a whole, in their being individuals compliant with society's morals and rules, and in their achieving high efficiency in their works, and being happier in their daily life. Apart from the benefits that physical education and sports activities provide to the individuals, they also have significant benefits to institutions and countries. They can promote, advertise and propagandize their countries or institutions by means of successes they achieve in sports organizations (İnal, 2003).

The peer tutoring method that is considered among the constructivist education models is the learning method that leads the student to actively participate in the courses, to participate in the discussion environment in the classroom and thus to learn actively, and in which the student is responsible for its own learning within the learning environment (Zhu, 2007).

In this education method, the teacher divides the subjects included in the unit into small sections that can be taught for the course hour. Students read the subject to be taught before coming to the classroom. The aim here is that the student has information, albeit superficial, on the subject, or that it sounds familiar. It can be checked, through a small question-and-answer method or by submission of the prepared reports to the teacher, whether the students have read the subject. Thus, it may be ensured that the students come prepared to the course. Furthermore, the teacher also is allowed to prepare for the course with regard to the information that the students have.

The peer education model in which two students with same academic success level mutually exchange as teacher and learner is called the mutual peer tutoring. The active learning method in which the student with high academic success level is teacher and the student with lower level is learner is called cross-peer tutoring. The cross-peer tutoring is not a widely preferred method. The common benefit in all techniques of the peer tutoring models is that the students who are at teacher and learner positions learn together (Mynard \& Almarzouqi, 2006).

The peer tutoring is a process in which a student, who received education and is capable of conducting peer tutoring, teaches, under guidance of a teacher, concepts or skills to one or more students at the same class level. The success of the peer tutoring is influenced by many factors such as age group, level of ability of teachers and learners, level of motivation for cooperation, nature of the concept or skill being taught. Therefore, the peer tutoring is an education model that includes different configurations. There are two configurations, namely one-way and class-wide peer tutoring (CWPT). In one-way peer tutoring, the student who knows the subject to be taught better helps the less knowing one. And in class-wide peer tutoring, the student charged with peer tutoring conducts, under the supervision of the teacher, the education with the whole class (Dudley et al., 2012; MEB, 2013). The peer education is a model that was developed as an alternative to the creation of power imbalance by the relationship - in the traditional education methods - that is based on hierarchy (MEB, 2010). The positive correlations in the students' performances found in the researches on peer education cause the application areas of the peer education model to expand (Can, 2009).

The objective of this research is to examine the effect of the peer education on the attitudes of secondary school students towards the course of physical education and sports.

\section{Materials and Methods}

The research in which the descriptive-survey method was used was carried out in two stages, namely theoretical and practical. In the theoretical stage, the literature related to the subject of the research was reviewed. The Attitude Scale in Physical Education and Sports (BESTÖ) developed by Demirhan and Altay (2001) will be used in order to determine students' attitudes towards Physical Education and Sports (Yeşiloğlu, 2015). (Annex 3). The construction validity of the Skill Attitude Scale used in the study was re-analyzed. In result of the conducted analysis, the Cronbach alpha value of the Physical Education Attitude Scale was calculated as .901 and the KMO (Kaiser-Meyer-Olkin Measure of Sampling Adequacy) value was calculated as .814. The universe and sample of the research; for the study group, the 7th grade students in two secondary schools, one of them being the school at which the researcher was positioned in the 2015-2016 school year, will be benefited from. The students at Atatürk Secondary School located in the Province of Elazığ, District of Maden and at Cumhuriyet Secondary School located in the District of Sivrice have been used. A total of 120 students, 30 in the control group and 30 in the experimental group, were studied at both schools. 


\section{Findings and Comments}

Table 1. Distribution by gender variable of the students participating in the research

\begin{tabular}{lcc}
\hline Gender & Frequency & Percentage \\
\hline Female & 61 & 50,8 \\
Male & 59 & 49,2 \\
Total & 120 & 100,0
\end{tabular}

When the information given in Table 1 were examined, it was determined that $50.8 \%$ of the students who participated in the research were female and $49.2 \%$ were male.

\subsection{Findings Related to the Application of Pretesting}

Table 2. Pretesting general opinions of the control group students, who participated in the research, about "The Course of Physical Education and Sports Attitudes"

\begin{tabular}{|c|c|c|c|c|c|c|c|c|c|}
\hline \multirow[t]{2}{*}{$\mathbf{M}$} & \multirow[t]{2}{*}{ The Course of Physical Education and Sports Attitude Scale } & \multirow[t]{2}{*}{$\mathbf{N}$} & \multicolumn{5}{|c|}{ Agreement Level (\%) } & \multirow{2}{*}{$\bar{X}$} & \multirow{2}{*}{ SS } \\
\hline & & & TKM & KM & $\mathbf{K}$ & KT & TK & & \\
\hline 1 & $\begin{array}{l}\text { In Physical Education and Sports classes, I always feel a sense of } \\
\text { fear. }\end{array}$ & 60 & 71,7 & 23,3 & 3,3 & 0 & 1,7 & 1,36 & 0,71 \\
\hline 2 & In Physical Education and Sports events, I get bored very much. & 60 & 63,3 & 23,3 & 5,0 & 3,3 & 5,0 & 1,63 & 1,07 \\
\hline 3 & $\begin{array}{l}\text { I am always shy of participating in Physical Education and Sports } \\
\text { events. }\end{array}$ & 60 & 60,0 & 25,0 & 8,3 & 1,7 & 5,0 & 1,66 & 1,05 \\
\hline 4 & $\begin{array}{l}\text { I do not make any effort to be successful in Physical Education and } \\
\text { Sports course. }\end{array}$ & 60 & 66,7 & 16,7 & 10,0 & 3,3 & 3,3 & 1,60 & 1,02 \\
\hline 5 & $\begin{array}{l}\text { I participate in Physical education and sports course because it is } \\
\text { compulsory as other courses. }\end{array}$ & 60 & 62,1 & 13,8 & 6,9 & 8,6 & 8,6 & 1,87 & 1,35 \\
\hline 6 & Talking about Physical Education and Sports is pleasurable. & 60 & 15,0 & 1,7 & 16,7 & 16,7 & 50,0 & 3,85 & 1,44 \\
\hline 7 & $\begin{array}{l}\text { Since I very much enjoy Physical Education and Sports, I look } \\
\text { forward to the class. }\end{array}$ & 60 & 11,7 & 0 & 8,3 & 26,7 & 53,3 & 4,10 & 1,29 \\
\hline 8 & $\begin{array}{l}\text { I refrain from coming to the forefront in Physical Education and } \\
\text { Sports class. }\end{array}$ & 60 & 53,3 & 23,3 & 10,0 & 8,3 & 5,0 & 1,88 & 1,19 \\
\hline 9 & $\begin{array}{l}\text { My sense of cooperation develops in Physical Education and Sports } \\
\text { class. }\end{array}$ & 60 & 6,8 & 13,6 & 13,6 & 23,7 & 42,4 & 3,81 & 1,30 \\
\hline 10 & Physical Education and Sports class teaches to be healthy and clean. & 60 & 6,7 & 3,2 & 11,7 & 21,7 & 56,7 & 4,18 & 1,18 \\
\hline 11 & $\begin{array}{l}\text { I do not want to take Physical Education and Sports class in my } \\
\text { future student life. }\end{array}$ & 60 & 50,8 & 15,3 & 23,7 & 1,7 & 8,5 & 2,01 & 1,26 \\
\hline 12 & $\begin{array}{l}\text { I believe that Physical Education and Sports activities contribute to } \\
\text { the healthy development of people. }\end{array}$ & 60 & 6,7 & 3,3 & 11,7 & 21,7 & 56,7 & 4,45 & 1,05 \\
\hline 13 & $\begin{array}{l}\text { It is not necessary to include Physical Education and Sports class in } \\
\text { school curriculum. }\end{array}$ & 60 & 50,8 & 15,3 & 23,7 & 1,7 & 8,5 & 1,69 & 1,24 \\
\hline 14 & $\begin{array}{l}\text { I believe that the pursuit of Physical Education and Sports will bring } \\
\text { significant benefits in my future life. }\end{array}$ & 60 & 6,7 & 11,7 & 15,0 & 16,7 & 50,0 & 3,91 & 1,31 \\
\hline 15 & $\begin{array}{l}\text { Every year of school curriculum should contain Physical Education } \\
\text { and Sports class. }\end{array}$ & 60 & 6,8 & 5,1 & 6,8 & 18,6 & 62,7 & 4,25 & 1,21 \\
\hline 16 & Participation in Physical Education and Sports activities rests me. & 60 & 6,6 & 11,7 & 11,7 & 20,0 & 50,0 & 3,95 & 1,30 \\
\hline 17 & $\begin{array}{l}\text { I believe that the activities related to Physical Education and Sports } \\
\text { gain honesty and democratic life behaviors. }\end{array}$ & 60 & 3,4 & 8,5 & 20,3 & 20,3 & 47,5 & 4,00 & 1,15 \\
\hline 18 & $\begin{array}{l}\text { I believe that free time is better made use of by exercising and } \\
\text { sporting. }\end{array}$ & 60 & 8,3 & 10,0 & 13,3 & 11,7 & 56,7 & 3,98 & 1,37 \\
\hline 19 & $\begin{array}{l}\text { I believe that engaging in Physical Education and Sports events is a } \\
\text { waste of time. }\end{array}$ & 60 & 65,0 & 16,7 & 5,0 & 6,7 & 6,7 & 1,73 & 1,23 \\
\hline 20 & I do not feel like doing exercise and sports during my free time. & 60 & 61,6 & 16,7 & 16,7 & 3,3 & 1,7 & 1,66 & 0,98 \\
\hline 21 & $\begin{array}{l}\text { I dedicate a significant amount of time for Physical Education and } \\
\text { Sport activities. }\end{array}$ & 60 & 8,3 & 13,3 & 20,0 & 18,3 & 40,0 & 3,68 & 1,34 \\
\hline 22 & $\begin{array}{l}\text { I have no interest in anything related to Physical Education and } \\
\text { Sports. }\end{array}$ & 60 & 68,3 & 20,0 & 5,0 & 3,3 & 3,3 & 1,53 & 0,98 \\
\hline 23 & Physical Education and Sports activities always attracts my interest. & 60 & 5,0 & 1,7 & 10,0 & 26,7 & 56,7 & 4,28 & 1,05 \\
\hline 24 & $\begin{array}{l}\text { I do not recommend other people to participate in Physical Education } \\
\text { and Sports activities. }\end{array}$ & 60 & 65,0 & 20,0 & 5,0 & 1,7 & 8,3 & 1,68 & 1,20 \\
\hline
\end{tabular}

TKM: I totally do not agree, KM: I do not agree, K: I am uncertain, KT: I agree, TK: I totally agree 
The distribution of general opinions of the control group students about their attitudes towards physical education and sports class is seen in Table 2. According to this, it is observed that the students, participating in the research, fully agree with some opinion items, agree with some items, are uncertain about some of them, and do not agree with some items.

When Table 2 is examined, it is seen that the students who participated in the research expressed their opinion about the opinion item "In Physical Education and Sports classes, I always feel a sense of fear" at the level of "I totally do not agree" $(\bar{X}=1,36)$.

When Table 2 is examined, it is seen that the students who participated in the research expressed their opinion about the opinion item "In Physical Education and Sports events, I get bored very much" at the level of "I totally do not agree" $(\bar{X}=1,63)$.

Again when Table 2 is examined, it is seen that the students who participated in the research expressed their opinion about the opinion item "I am always shy of participating in Physical Education and Sports events" at the level of "I totally do not agree" $(\bar{X}=1,66)$, about the opinion item " I do not make any effort to be successful in Physical Education and Sports course " at the level of "I totally do not agree" $(\bar{X}=1,60)$, about the opinion item "I participate in Physical education and sports course because it is compulsory as other courses" at the level of "I do not agree " $(\bar{X}=1,87)$ although it was close to "I totally do not agree", about the opinion item "Talking about Physical Education and Sports is pleasurable" at the level of "I agree" $(\bar{X}=3,85)$, about the opinion item "Since I very much enjoy Physical Education and Sports, I look forward to the class" at the level of "I agree" $(\bar{X}=4,10)$ although it was close to "I totally agree", about the opinion item "I refrain from coming to the forefront in Physical Education and Sports class" at the level "I do not agree" $(\bar{X}=1,88)$, about the opinion item "My sense of cooperation develops in Physical Education and Sports class" at the level of "I agree" $(\bar{X}=3,81)$, about the opinion item "Physical Education and Sports class teaches to be healthy and clean" at the level of "I do not agree" $(\bar{X}=4,18)$ although it was close to "I totally agree".

When Table 2 is examined, it is seen that those who participated in the research expressed their opinion about the opinion item "I do not want to take Physical Education and Sports class in my future student life" at the level of "I do not agree" $(\bar{X}=2,01)$, about the opinion item "I believe that Physical Education and Sports activities contribute to the healthy development of people" at the level of "I totally agree" $(\bar{X}=4,45)$, about the opinion item "It is not necessary to include Physical Education and Sports class in school curriculum" at the level of "I totally do not agree " $(\bar{X}=1,69)$ although it was close to "I do not agree", about the opinion item "I believe that the pursuit of Physical Education and Sports will bring significant benefits in my future life" at the level of "I agree" $(\bar{X}=3,91)$, about the opinion item "Every year of school curriculum should contain Physical Education and Sports class" at the level of "I totally agree " $(\bar{X}=4,25)$ although it was close to "I agree", about the opinion item "Participation in Physical Education and Sports activities rests me" at the level "I agree" $(\bar{X}=3,95)$, about the opinion item "I believe that the activities related to Physical Education and Sports gain honesty and democratic life behaviors" at the level of "I agree" $(\bar{X}=4,00)$, about the opinion item "I believe that free time is better made use of by exercising and sporting" at the level of "I agree" $(\bar{X}=3,98)$ although it was close to "I totally agree".

Again when Table 2 is examined, it is seen that those who participated in the research expressed their opinion about the opinion item "I believe that engaging in Physical Education and Sports events is a waste of time" at the level of "I totally do not agree" $(\bar{X}=1,73)$ although it was close to "I do not agree", about the opinion item "I do not feel like doing exercise and sports during my free time" at the level of "I totally do not agree" $(\bar{X}=1,66)$ although it was close to "I do not agree", about the opinion item "I dedicate a significant amount of time for Physical Education and Sport activities" at the level of "I agree" $(\bar{X}=3,68)$, about the opinion item "I have no interest in anything related to Physical Education and Sports" at the level of "I totally do not agree" $(\bar{X}=1,53)$, about the opinion item "Physical Education and Sports activities always attracts my interest" at the level of "I totally agree" $(\bar{X}=4,28)$ although it was close to "I agree", about the opinion item "I do not recommend other people to participate in Physical Education and Sports activities" at the level "I totally do not agree" $(\bar{X}=1,68)$. 
Table 3. Pretesting general opinions of the experimental group students, who participated in the research, about "The Course of Physical Education and Sports Attitudes"

\begin{tabular}{|c|c|c|c|c|c|c|c|c|c|}
\hline \multirow[t]{2}{*}{$\mathbf{M}$} & \multirow[t]{2}{*}{ The Course of Physical Education and Sports Attitude Scale } & \multirow[t]{2}{*}{$\mathbf{N}$} & \multicolumn{5}{|c|}{ Agreement Level (\%) } & \multirow{2}{*}{$\bar{X}$} & \multirow{2}{*}{ SS } \\
\hline & & & TKM & KM & $\mathbf{K}$ & KT & TK & & \\
\hline 1 & $\begin{array}{l}\text { In Physical Education and Sports classes, I always feel a sense of } \\
\text { fear. }\end{array}$ & 60 & 81,4 & 15,3 & 3,4 & 0 & 0 & 1,22 & 0,49 \\
\hline 2 & In Physical Education and Sports events, I get bored very much. & 60 & 76,7 & 8,3 & 5,0 & 3,3 & 6,7 & 1,55 & 1,17 \\
\hline 3 & $\begin{array}{l}\text { I am always shy of participating in Physical Education and Sports } \\
\text { events. }\end{array}$ & 60 & 75,0 & 15,0 & 5,0 & 3,3 & 1,7 & 1,41 & 0,86 \\
\hline 4 & $\begin{array}{l}\text { I do not make any effort to be successful in Physical Education and } \\
\text { Sports course. }\end{array}$ & 60 & 73,3 & 13,3 & 10,0 & 1,7 & 1,7 & 1,45 & 0,87 \\
\hline 5 & $\begin{array}{l}\text { I participate in Physical education and sports course because it is } \\
\text { compulsory as other courses. }\end{array}$ & 60 & 62,1 & 13,8 & 3,4 & 8,6 & 12,1 & 1,94 & 1,45 \\
\hline 6 & Talking about Physical Education and Sports is pleasurable. & 60 & 16,7 & 5,0 & 6,7 & 13,3 & 58,3 & 3,91 & 1,54 \\
\hline 7 & $\begin{array}{l}\text { Since I very much enjoy Physical Education and Sports, I look } \\
\text { forward to the class. }\end{array}$ & 60 & 8,3 & 5,0 & 18,3 & 11,7 & 56,7 & 4,03 & 1,31 \\
\hline 8 & $\begin{array}{l}\text { I refrain from coming to the forefront in Physical Education and } \\
\text { Sports class. }\end{array}$ & 60 & 54,2 & 15,3 & 8,5 & 8,5 & 13,6 & 2,11 & 1,48 \\
\hline 9 & $\begin{array}{l}\text { My sense of cooperation develops in Physical Education and Sports } \\
\text { class. }\end{array}$ & 60 & 10,3 & 6,9 & 10,3 & 25,9 & 46,6 & 3,91 & 1,34 \\
\hline 10 & Physical Education and Sports class teaches to be healthy and clean. & 60 & 3,4 & 6,8 & 8,5 & 20,3 & 61,0 & 4,28 & 1,09 \\
\hline 11 & $\begin{array}{l}\text { I do not want to take Physical Education and Sports class in my } \\
\text { future student life. }\end{array}$ & 60 & 55,0 & 6,7 & 10,0 & 8,3 & 20,0 & 2,31 & 1,65 \\
\hline 12 & $\begin{array}{l}\text { I believe that Physical Education and Sports activities contribute to } \\
\text { the healthy development of people. }\end{array}$ & 60 & 62,7 & 11,9 & 15,3 & 1,7 & 8,5 & 4,30 & 1,20 \\
\hline 13 & $\begin{array}{l}\text { It is not necessary to include Physical Education and Sports class in } \\
\text { school curriculum. }\end{array}$ & 60 & 62,7 & 11,9 & 15,3 & 1,7 & 8,5 & 1,81 & 1,26 \\
\hline 14 & $\begin{array}{l}\text { I believe that the pursuit of Physical Education and Sports will bring } \\
\text { significant benefits in my future life. }\end{array}$ & 60 & 3,4 & 3,4 & 16,9 & 15,3 & 61,0 & 4,27 & 1,08 \\
\hline 15 & $\begin{array}{l}\text { Every year of school curriculum should contain Physical Education } \\
\text { and Sports class. }\end{array}$ & 60 & 6,8 & 1,7 & 13,6 & 13,5 & 64,4 & 4,27 & 1,18 \\
\hline 16 & Participation in Physical Education and Sports activities rests me. & 60 & 7,0 & 5,3 & 15,8 & 19,3 & 52,6 & 4,05 & 1,24 \\
\hline 17 & $\begin{array}{l}\text { I believe that the activities related to Physical Education and Sports } \\
\text { gain honesty and democratic life behaviors. }\end{array}$ & 60 & 6,7 & 6,7 & 18,3 & 21,7 & 46,7 & 3,95 & 1,24 \\
\hline 18 & $\begin{array}{l}\text { I believe that free time is better made use of by exercising and } \\
\text { sporting. }\end{array}$ & 60 & 5,1 & 5,1 & 11,9 & 16,9 & 61,0 & 4,23 & 1,16 \\
\hline 19 & $\begin{array}{l}\text { I believe that engaging in Physical Education and Sports events is a } \\
\text { waste of time. }\end{array}$ & 60 & 59,3 & 13,6 & 10,2 & 5,1 & 11,9 & 1,96 & 1,41 \\
\hline 20 & I do not feel like doing exercise and sports during my free time. & 60 & 53,4 & 22,4 & 3,4 & 15,5 & 5,2 & 1,96 & 1,29 \\
\hline 21 & $\begin{array}{l}\text { I dedicate a significant amount of time for Physical Education and } \\
\text { Sport activities. }\end{array}$ & 60 & 13,8 & 12,1 & 10,3 & 20,7 & 43,1 & 3,67 & 1,47 \\
\hline 22 & $\begin{array}{l}\text { I have no interest in anything related to Physical Education and } \\
\text { Sports. }\end{array}$ & 60 & 58,6 & 12,1 & 10,3 & 8,6 & 10,3 & 2,00 & 1,41 \\
\hline 23 & Physical Education and Sports activities always attracts my interest. & 60 & 16,9 & 3,4 & 10,2 & 10,2 & 59,3 & 3,91 & 1,54 \\
\hline 24 & $\begin{array}{l}\text { I do not recommend other people to participate in Physical Education } \\
\text { and Sports activities. }\end{array}$ & 60 & 72,9 & 11,9 & 5,0 & 5,1 & 5,1 & 1,57 & 1,13 \\
\hline
\end{tabular}

TKM: I totally do not agree, KM: I do not agree, K: I am uncertain, KT: I agree, TK: I totally agree

The distribution of general opinions of the experimental group students about their attitudes towards physical education and sports class is seen in Table 3. According to this, it is observed that the students, participating in the research, fully agree with some opinion items, agree with some items, are uncertain about some of them, and do not agree with some items.

When Table 3 is examined, it is seen that the students who participated in the research expressed their opinion about the opinion item "In Physical Education and Sports classes, I always feel a sense of fear" at the level of "I totally do not agree" $(\bar{X}=1,22)$.

When Table 3 is examined, it is seen that the students who participated in the research expressed their opinion about the opinion item "In Physical Education and Sports events, I get bored very much" at the level of "I totally do not agree" $(\bar{X}=1,55)$.

Again when Table 3 is examined, it is seen that the students who participated in the research expressed their opinion 
about the opinion item "I am always shy of participating in Physical Education and Sports events" at the level of "I totally do not agree" $(\bar{X}=1,41)$, about the opinion item "I do not make any effort to be successful in Physical Education and Sports course" at the level of "I totally do not agree" $(\bar{X}=1,45)$, about the opinion item "I participate in Physical education and sports course because it is compulsory as other courses" at the level of "I do not agree " $(\bar{X}=1,94)$ although it was close to "I totally do not agree", about the opinion item "Talking about Physical Education and Sports is pleasurable" at the level of "I agree" $(\bar{X}=3,91)$, about the opinion item "Since I very much enjoy Physical Education and Sports, I look forward to the class" at the level of "I agree" $(\bar{X}=4,03)$ although it was close to "I totally agree", about the opinion item "I refrain from coming to the forefront in Physical Education and Sports class" at the level "I do not agree" $(\bar{X}=2,11)$, about the opinion item "My sense of cooperation develops in Physical Education and Sports class" at the level of "I agree" $(\bar{X}=3,91)$, about the opinion item "Physical Education and Sports class teaches to be healthy and clean" at the level of "I totally do not agree" $(\bar{X}=4,28)$ although it was close to "I agree".

When Table 3 is examined, it is seen that those who participated in the research expressed their opinion about the opinion item "I do not want to take Physical Education and Sports class in my future student life" at the level of "I do not agree" $(\bar{X}=2,31)$, about the opinion item "I believe that Physical Education and Sports activities contribute to the healthy development of people" at the level of "I totally agree" $(\bar{X}=4,30)$, about the opinion item "It is not necessary to include Physical Education and Sports class in school curriculum" at the level of "I do not agree " $(\bar{X}=1,81)$ although it was close to "I totally do not agree", about the opinion item "I believe that the pursuit of Physical Education and Sports will bring significant benefits in my future life" at the level of "I totally agree" $(\bar{X}=4,27)$ although it was close to "I agree", about the opinion item "Every year of school curriculum should contain Physical Education and Sports class" at the level of "I totally agree " $(\bar{X}=4,27)$ although it was close to "I agree", about the opinion item "Participation in Physical Education and Sports activities rests me" at the level "I agree" $(\bar{X}=4,05)$, about the opinion item "I believe that the activities related to Physical Education and Sports gain honesty and democratic life behaviors" at the level of "I agree" $(\bar{X}=3,95)$, about the opinion item "I believe that free time is better made use of by exercising and sporting" at the level of "I totally agree" $(\bar{X}=4,23)$ although it was close to "I agree".

Again when Table 2 is examined, it is seen that those who participated in the research expressed their opinion about the opinion item "I believe that engaging in Physical Education and Sports events is a waste of time" at the level of "I do not agree" $(\bar{X}=1,96)$ although it was close to "I totally do not agree", about the opinion item "I do not feel like doing exercise and sports during my free time" at the level of "I do not agree" $(\bar{X}=1,96)$ although it was close to "I totally do not agree", about the opinion item "I dedicate a significant amount of time for Physical Education and Sport activities" at the level of "I agree" $(\bar{X}=3,67)$, about the opinion item "I have no interest in anything related to Physical Education and Sports" at the level of "I do not agree" $(\bar{X}=2,00)$, about the opinion item "Physical Education and Sports activities always attracts my interest" at the level of "I agree" $(\bar{X}=3,91)$, about the opinion item "I do not recommend other people to participate in Physical Education and Sports activities" at the level "I totally do not agree" $(\bar{X}=1,57)$. 


\subsection{Findings Related to the Posttest Applications}

Table 4. Posttest general opinions of the control group students, who participated in the research, about "The Course of Physical Education and Sports Attitudes"

\begin{tabular}{|c|c|c|c|c|c|c|c|c|c|}
\hline \multirow[t]{2}{*}{ M } & \multirow[t]{2}{*}{ The Course of Physical Education and Sports Attitude Scale } & \multirow[t]{2}{*}{$\mathbf{N}$} & \multicolumn{5}{|c|}{ Agreement Level (\%) } & \multirow{2}{*}{$\bar{X}$} & \multirow[b]{2}{*}{ SS } \\
\hline & & & TKM & $\mathbf{K M}$ & $\mathbf{K}$ & KT & TK & & \\
\hline 1 & $\begin{array}{l}\text { In Physical Education and Sports classes, I always feel a sense of } \\
\text { fear. }\end{array}$ & 60 & 93,3 & 5,0 & 1,7 & 0 & 0 & 1,08 & 0,33 \\
\hline 2 & In Physical Education and Sports events, I get bored very much. & 60 & 75,0 & 23,3 & 1,7 & 0 & 0 & 1,26 & 0,48 \\
\hline 3 & $\begin{array}{l}\text { I am always shy of participating in Physical Education and Sports } \\
\text { events. }\end{array}$ & 60 & 86,7 & 5,0 & 6,7 & 1,7 & 0 & 1,23 & 0,64 \\
\hline 4 & $\begin{array}{l}\text { I do not make any effort to be successful in Physical Education and } \\
\text { Sports course. }\end{array}$ & 60 & 78,3 & 11,7 & 6,7 & 1,7 & 1,7 & 1,36 & 0,82 \\
\hline 5 & $\begin{array}{l}\text { I participate in Physical education and sports course because it is } \\
\text { compulsory as other courses. }\end{array}$ & 60 & 72,9 & 8,5 & 1,7 & 5,1 & 11,9 & 1,74 & 1,40 \\
\hline 6 & Talking about Physical Education and Sports is pleasurable. & 60 & 5,0 & 5,0 & 1,7 & 13,3 & 75,0 & 4,48 & 1,09 \\
\hline 7 & $\begin{array}{l}\text { Since I very much enjoy Physical Education and Sports, I look } \\
\text { forward to the class. }\end{array}$ & 60 & 0 & 8,4 & 0 & 18,3 & 73,3 & 4,56 & 0,87 \\
\hline 8 & $\begin{array}{l}\text { I refrain from coming to the forefront in Physical Education and } \\
\text { Sports class. }\end{array}$ & 60 & 58,3 & 13,3 & 16,7 & 6,7 & 5,0 & 1,86 & 1,21 \\
\hline 9 & $\begin{array}{l}\text { My sense of cooperation develops in Physical Education and Sports } \\
\text { class. }\end{array}$ & 60 & 5,0 & 0 & 15,0 & 13,3 & 66,7 & 4,36 & 1,07 \\
\hline 10 & Physical Education and Sports class teaches to be healthy and clean. & 60 & 3,4 & 6,8 & 6,8 & 5,1 & 78,0 & 4,47 & 1,10 \\
\hline 11 & $\begin{array}{l}\text { I do not want to take Physical Education and Sports class in my } \\
\text { future student life. }\end{array}$ & 60 & 68,3 & 11,7 & 5,0 & 3,3 & 11,7 & 1,78 & 1,37 \\
\hline 12 & $\begin{array}{l}\text { I believe that Physical Education and Sports activities contribute to } \\
\text { the healthy development of people. }\end{array}$ & 60 & 3,3 & 0 & 6,7 & 13,3 & 76,7 & 4,60 & 0,88 \\
\hline 13 & $\begin{array}{l}\text { It is not necessary to include Physical Education and Sports class in } \\
\text { school curriculum. }\end{array}$ & 60 & 81,4 & 6,8 & 3,4 & 6,8 & 1,7 & 1,40 & 0,96 \\
\hline 14 & $\begin{array}{l}\text { I believe that the pursuit of Physical Education and Sports will bring } \\
\text { significant benefits in my future life. }\end{array}$ & 60 & 3,4 & 5,1 & 8,5 & 11,9 & 71,2 & 4,42 & 1,07 \\
\hline 15 & $\begin{array}{l}\text { Every year of school curriculum should contain Physical Education } \\
\text { and Sports class. }\end{array}$ & 60 & 5,1 & 3,4 & 8,5 & 5,1 & 78,0 & 4,47 & 1,11 \\
\hline 16 & Participation in Physical Education and Sports activities rests me. & 60 & 11,9 & 6,8 & 5,1 & 15,3 & 61,0 & 4,06 & 1,42 \\
\hline 17 & $\begin{array}{l}\text { I believe that the activities related to Physical Education and Sports } \\
\text { gain honesty and democratic life behaviors. }\end{array}$ & 60 & 8,3 & 5,0 & 18,3 & 10,0 & 58,3 & 4,05 & 1,32 \\
\hline 18 & $\begin{array}{l}\text { I believe that free time is better made use of by exercising and } \\
\text { sporting. }\end{array}$ & 60 & 3,3 & 3,3 & 3,3 & 10,1 & 80,0 & 4,60 & 0,96 \\
\hline 19 & $\begin{array}{l}\text { I believe that engaging in Physical Education and Sports events is a } \\
\text { waste of time. }\end{array}$ & 60 & 78,3 & 10,0 & 3,3 & 3,3 & 5,1 & 1,46 & 1,06 \\
\hline 20 & I do not feel like doing exercise and sports during my free time. & 60 & 68,3 & 13,3 & 11,7 & 3,3 & 3,4 & 1,60 & 1,04 \\
\hline 21 & $\begin{array}{l}\text { I dedicate a significant amount of time for Physical Education and } \\
\text { Sport activities. }\end{array}$ & 60 & 8,3 & 11,7 & 18,3 & 13,3 & 48,3 & 3,81 & 1,37 \\
\hline 22 & $\begin{array}{l}\text { I have no interest in anything related to Physical Education and } \\
\text { Sports. }\end{array}$ & 60 & 76,7 & 18,3 & 1,7 & 0 & 3,3 & 1,35 & 0,81 \\
\hline 23 & Physical Education and Sports activities always attracts my interest. & 60 & 3,3 & 8,3 & 11,7 & 10,0 & 66,7 & 4,28 & 1,16 \\
\hline 24 & $\begin{array}{l}\text { I do not recommend other people to participate in Physical Education } \\
\text { and Sports activities. }\end{array}$ & 60 & 76,7 & 11,7 & 5,0 & 3,3 & 3,3 & 1,45 & 0,98 \\
\hline
\end{tabular}

TKM: I totally do not agree, KM: I do not agree, K: I am uncertain, KT: I agree, TK: I totally agree

The distribution of general opinions of the control group students about their attitudes towards physical education and sports class is seen in Table 4. According to this, it is observed that the students, participating in the research, fully agree with some opinion items, agree with some items, are uncertain about some of them, and do not agree with some items.

When Table 4 is examined, it is seen that the students who participated in the research expressed their opinion about the opinion item "In Physical Education and Sports classes, I always feel a sense of fear" at the level of "I totally do not agree" $(\bar{X}=1,08)$.

When Table 4 is examined, it is seen that the students who participated in the research expressed their opinion about the opinion item "In Physical Education and Sports events, I get bored very much" at the level of "I totally do not agree" $(\bar{X}=1,26)$.

Again when Table 4 is examined, it is seen that the students who participated in the research expressed their opinion 
about the opinion item "I am always shy of participating in Physical Education and Sports events" at the level of "I totally do not agree" $(\bar{X}=1,2)$, about the opinion item " I do not make any effort to be successful in Physical Education and Sports course" at the level of "I totally do not agree" $(\bar{X}=1,36)$, about the opinion item "I participate in Physical education and sports course because it is compulsory as other courses" at the level of "I do not agree " $(\bar{X}=1,74)$ although it was close to "I totally do not agree", about the opinion item "Talking about Physical Education and Sports is pleasurable" at the level of "I totally agree" $(\bar{X}=4,48)$, about the opinion item "Since I very much enjoy Physical Education and Sports, I look forward to the class" at the level of "I agree" $(\bar{X}=4,56)$ although it was close to "I totally agree", about the opinion item "I refrain from coming to the forefront in Physical Education and Sports class" at the level "I do not agree" $(\bar{X}=1,86)$ although it was close to "I totally do not agree", about the opinion item "My sense of cooperation develops in Physical Education and Sports class" at the level of "I totally agree" $(\bar{X}=4,36)$, about the opinion item "Physical Education and Sports class teaches to be healthy and clean" at the level of "I totally agree" $(\bar{X}=4,47)$.

When Table 4 is examined, it is seen that those who participated in the research expressed their opinion about the opinion item "I do not want to take Physical Education and Sports class in my future student life" at the level of "I totally do not agree" $(\bar{X}=1,78)$ although it was close to "I do not agree", about the opinion item "I believe that Physical Education and Sports activities contribute to the healthy development of people" at the level of "I totally agree" $(\bar{X}=4,60)$, about the opinion item "It is not necessary to include Physical Education and Sports class in school curriculum" at the level of "I totally do not agree " $(\bar{X}=1,40)$, about the opinion item "I believe that the pursuit of Physical Education and Sports will bring significant benefits in my future life" at the level of "I agree" $(\bar{X}=4,42)$, about the opinion item "Every year of school curriculum should contain Physical Education and Sports class" at the level of "I totally agree " $(\bar{X}=4,47)$ although it was close to "I agree", about the opinion item "Participation in Physical Education and Sports activities rests me" at the level "I agree" $(\bar{X}=4,06)$, about the opinion item "I believe that the activities related to Physical Education and Sports gain honesty and democratic life behaviors" at the level of "I agree" $(\bar{X}=4,05)$, about the opinion item "I believe that free time is better made use of by exercising and sporting" at the level of "I totally agree" $(\bar{X}=4,60)$ although it was close to "I agree".

Again when Table 4 is examined, it is seen that those who participated in the research expressed their opinion about the opinion item "I believe that engaging in Physical Education and Sports events is a waste of time" at the level of "I totally do not agree" $(\bar{X}=1,46)$, about the opinion item "I do not feel like doing exercise and sports during my free time" at the level of "I totally do not agree" $(\bar{X}=1,60)$, about the opinion item "I dedicate a significant amount of time for Physical Education and Sport activities" at the level of "I agree" $(\bar{X}=3,81)$, about the opinion item "I have no interest in anything related to Physical Education and Sports" at the level of "I totally do not agree" $(\bar{X}=1,35)$, about the opinion item "Physical Education and Sports activities always attracts my interest" at the level of "I totally agree" $(\bar{X}=4,28)$ although it was close to "I agree", about the opinion item "I do not recommend other people to participate in Physical Education and Sports activities" at the level "I totally do not agree" $(\bar{X}=1,45)$. 
Table 5. Posttest general opinions of the experimental group students, who participated in the research, about "The Course of Physical Education and Sports Attitudes"

\begin{tabular}{|c|c|c|c|c|c|c|c|c|c|}
\hline \multirow[t]{2}{*}{$\mathbf{M}$} & \multirow[t]{2}{*}{ The Course of Physical Education and Sports Attitude Scale } & \multirow[t]{2}{*}{$\mathbf{N}$} & \multicolumn{5}{|c|}{ Agreement Level (\%) } & \multirow[t]{2}{*}{$\bar{X}$} & \multirow[b]{2}{*}{ SS } \\
\hline & & & TKM & KM & $\mathbf{K}$ & KT & TK & & \\
\hline 1 & $\begin{array}{l}\text { In Physical Education and Sports classes, I always feel a sense of } \\
\text { fear. }\end{array}$ & 60 & 86,4 & 5,1 & 3,4 & 0 & 5,1 & 1,32 & 0,95 \\
\hline 2 & In Physical Education and Sports events, I get bored very much. & 60 & 85,0 & 3,3 & 6,7 & 1,7 & 3,3 & 1,35 & 0,93 \\
\hline 3 & $\begin{array}{l}\text { I am always shy of participating in Physical Education and Sports } \\
\text { events. }\end{array}$ & 60 & 88,3 & 5,0 & 1,7 & 5,0 & 0 & 1,23 & 0,72 \\
\hline 4 & $\begin{array}{l}\text { I do not make any effort to be successful in Physical Education and } \\
\text { Sports course. }\end{array}$ & 60 & 83,1 & 8,5 & 1,7 & 0 & 6,8 & 1,38 & 1,05 \\
\hline 5 & $\begin{array}{l}\text { I participate in Physical education and sports course because it is } \\
\text { compulsory as other courses. }\end{array}$ & 60 & 73,3 & 11,7 & 1,7 & 6,7 & 6,7 & 1,61 & 1,22 \\
\hline 6 & Talking about Physical Education and Sports is pleasurable. & 60 & 11,9 & 3,4 & 3,4 & 11,9 & 69,5 & 4,23 & 1,38 \\
\hline 7 & $\begin{array}{l}\text { Since I very much enjoy Physical Education and Sports, I look } \\
\text { forward to the class. }\end{array}$ & 60 & 11,7 & 8,3 & 1,7 & 8,3 & 70,0 & 4,16 & 1,45 \\
\hline 8 & $\begin{array}{l}\text { I refrain from coming to the forefront in Physical Education and } \\
\text { Sports class. }\end{array}$ & 60 & 72,9 & 6,8 & 8,5 & 8,5 & 3,4 & 1,62 & 1,15 \\
\hline 9 & $\begin{array}{l}\text { My sense of cooperation develops in Physical Education and Sports } \\
\text { class. }\end{array}$ & 60 & 10,0 & 3,3 & 13,3 & 10,0 & 63,3 & 4,13 & 1,34 \\
\hline 10 & Physical Education and Sports class teaches to be healthy and clean. & 60 & 11,7 & 8,3 & 5,0 & 10,0 & 65,0 & 4,08 & 1,45 \\
\hline 11 & $\begin{array}{l}\text { I do not want to take Physical Education and Sports class in my } \\
\text { future student life. }\end{array}$ & 60 & 71,2 & 3,4 & 8,5 & 1,7 & 15,3 & 1,86 & 1,50 \\
\hline 12 & $\begin{array}{l}\text { I believe that Physical Education and Sports activities contribute to } \\
\text { the healthy development of people. }\end{array}$ & 60 & 8,5 & 1,7 & 5,1 & 8,5 & 76,3 & 4,42 & 1,22 \\
\hline 13 & $\begin{array}{l}\text { It is not necessary to include Physical Education and Sports class in } \\
\text { school curriculum. }\end{array}$ & 60 & 76,3 & 5,0 & 1,7 & 5,1 & 11,9 & 1,71 & 1,41 \\
\hline 14 & $\begin{array}{l}\text { I believe that the pursuit of Physical Education and Sports will bring } \\
\text { significant benefits in my future life. }\end{array}$ & 60 & 6,7 & 5,0 & 6,7 & 1,7 & 80,0 & 4,43 & 1,22 \\
\hline 15 & $\begin{array}{l}\text { Every year of school curriculum should contain Physical Education } \\
\text { and Sports class. }\end{array}$ & 60 & 13,3 & 1,7 & 3,3 & 8,3 & 73,3 & 4,26 & 1,41 \\
\hline 16 & Participation in Physical Education and Sports activities rests me. & 60 & 15,0 & 5,0 & 1,7 & 15,0 & 63,3 & 4,06 & 1,49 \\
\hline 17 & $\begin{array}{l}\text { I believe that the activities related to Physical Education and Sports } \\
\text { gain honesty and democratic life behaviors. }\end{array}$ & 60 & 15,3 & 3,4 & 10,2 & 23,7 & 47,5 & 3,84 & 1,44 \\
\hline 18 & $\begin{array}{l}\text { I believe that free time is better made use of by exercising and } \\
\text { sporting. }\end{array}$ & 60 & 18,3 & 3,3 & 0 & 6,7 & 71,7 & 4,10 & 1,59 \\
\hline 19 & $\begin{array}{l}\text { I believe that engaging in Physical Education and Sports events is a } \\
\text { waste of time. }\end{array}$ & 60 & 71,7 & 8,3 & 1,7 & 0 & 18,3 & 1,85 & 1,54 \\
\hline 20 & I do not feel like doing exercise and sports during my free time. & 60 & 65,5 & 10,3 & 8,6 & 1,7 & 13,8 & 1,87 & 1,43 \\
\hline 21 & $\begin{array}{l}\text { I dedicate a significant amount of time for Physical Education and } \\
\text { Sport activities. }\end{array}$ & 60 & 18,3 & 8,3 & 10,0 & 6,7 & 56,7 & 3,75 & 1,62 \\
\hline 22 & $\begin{array}{l}\text { I have no interest in anything related to Physical Education and } \\
\text { Sports. }\end{array}$ & 60 & 76,3 & 3,4 & 1,7 & 5,1 & 13,6 & 1,76 & 1,47 \\
\hline 23 & Physical Education and Sports activities always attracts my interest. & 60 & 13,6 & 1,7 & 3,4 & 3,4 & 78,0 & 4,30 & 1,42 \\
\hline 24 & $\begin{array}{l}\text { I do not recommend other people to participate in Physical Education } \\
\text { and Sports activities. }\end{array}$ & 60 & 75,0 & 6,7 & 5,0 & 1,7 & 11,7 & 1,68 & 1,35 \\
\hline
\end{tabular}

TKM: I totally do not agree, KM: I do not agree, K: I am uncertain, KT: I agree, TK: I totally agree

The distribution of general opinions of the experimental group students about their attitudes towards physical education and sports class is seen in Table 5. According to this, it is observed that the students, participating in the research, fully agree with some opinion items, agree with some items, are uncertain about some of them, and do not agree with some items.

When Table 5 is examined, it is seen that the students who participated in the research expressed their opinion about the opinion item "In Physical Education and Sports classes, I always feel a sense of fear" at the level of "I totally do not agree" $(\bar{X}=1,32)$.

When Table 5 is examined, it is seen that the students who participated in the research expressed their opinion about the opinion item "In Physical Education and Sports events, I get bored very much" at the level of "I totally do not agree" $(\bar{X}=1,35)$.

Again when Table 5 is examined, it is seen that the students who participated in the research expressed their opinion 
about the opinion item "I am always shy of participating in Physical Education and Sports events" at the level of "I totally do not agree" $(\bar{X}=1,2)$, about the opinion item " I do not make any effort to be successful in Physical Education and Sports course" at the level of "I totally do not agree" $(\bar{X}=1,38)$, about the opinion item "I participate in Physical education and sports course because it is compulsory as other courses" at the level of "I do not agree " $(\bar{X}=1,61)$ although it was close to "I totally do not agree", about the opinion item "Talking about Physical Education and Sports is pleasurable" at the level of "I totally agree" $(\bar{X}=4,23)$ although it was close to "I agree", about the opinion item "Since I very much enjoy Physical Education and Sports, I look forward to the class" at the level of "I agree" $(\bar{X}=4,16)$ although it was close to "I totally agree", about the opinion item "I refrain from coming to the forefront in Physical Education and Sports class" at the level "I totally do not agree" $(\bar{X}=1,62)$ although it was close to "I do not agree", about the opinion item "My sense of cooperation develops in Physical Education and Sports class" at the level of "I agree" $(\bar{X}=4,13)$ although it was close to "I totally agree", about the opinion item "Physical Education and Sports class teaches to be healthy and clean" at the level of "I agree" $(\bar{X}=4,08)$.

When Table 5 is examined, it is seen that those who participated in the research expressed their opinion about the opinion item "I do not want to take Physical Education and Sports class in my future student life" at the level of "I do not agree" $(\bar{X}=1,86)$ although it was close to "I totally do not agree", about the opinion item "I believe that Physical Education and Sports activities contribute to the healthy development of people" at the level of "I totally agree" $(\bar{X}=4,42)$, about the opinion item "It is not necessary to include Physical Education and Sports class in school curriculum" at the level of "I totally do not agree " $(\bar{X}=1,71)$, about the opinion item "I believe that the pursuit of Physical Education and Sports will bring significant benefits in my future life" at the level of "I totally agree" $(\bar{X}=4,43)$, about the opinion item "Every year of school curriculum should contain Physical Education and Sports class" at the level of "I totally agree " $(\bar{X}=4,26)$ although it was close to "I agree", about the opinion item "Participation in Physical Education and Sports activities rests me" at the level "I agree" $(\bar{X}=4,06)$, about the opinion item "I believe that the activities related to Physical Education and Sports gain honesty and democratic life behaviors" at the level of "I agree" $(\bar{X}=3,84)$, about the opinion item "I believe that free time is better made use of by exercising and sporting" at the level of "I totally agree" $(\bar{X}=4,10)$ although it was close to "I agree".

Again when Table 5 is examined, it is seen that those who participated in the research expressed their opinion about the opinion item "I believe that engaging in Physical Education and Sports events is a waste of time" at the level of "I do not agree" $(\bar{X}=1,85)$ although it was close to "I totally do not agree", about the opinion item "I do not feel like doing exercise and sports during my free time" at the level of "I do not agree" $(\bar{X}=1,87)$ although it was close to "I totally do not agree", about the opinion item "I dedicate a significant amount of time for Physical Education and Sport activities" at the level of "I agree" $(\bar{X}=3,75)$, about the opinion item "I have no interest in anything related to Physical Education and Sports" at the level of "I totally do not agree" $(\bar{X}=1,76)$, about the opinion item "Physical Education and Sports activities always attracts my interest" at the level of "I totally agree" $(\bar{X}=4,30)$ although it was close to "I agree", about the opinion item "I do not recommend other people to participate in Physical Education and Sports activities" at the level "I totally do not agree" $(\bar{X}=1,68)$. 
Table 6. Relative group t test results of the experimental group students participating in the research

\begin{tabular}{|c|c|c|c|c|c|c|}
\hline The Course of Physical Education and Sports Attitude & $\begin{array}{l}\text { Test } \\
\text { Time }\end{array}$ & $\mathrm{N}$ & $\bar{X}$ & Ss & $\mathrm{T}$ & $\mathrm{p}$ \\
\hline \multirow[t]{2}{*}{ In Physical Education and Sports classes, I always feel a sense of fear. } & Pretest & 60 & 1,32 & 0,95 & \multirow{2}{*}{2,032} & \multirow{2}{*}{$0,047 *$} \\
\hline & Posttest & 60 & 1,08 & 0,33 & & \\
\hline \multirow[t]{2}{*}{ In Physical Education and Sports events, I get bored very much. } & Pretest & 60 & 1,35 & 0,93 & \multirow{2}{*}{0,637} & \multirow{2}{*}{0,527} \\
\hline & Posttest & 60 & 1,26 & 0,48 & & \\
\hline \multirow{2}{*}{$\begin{array}{l}\text { I am always shy of participating in Physical Education and Sports } \\
\text { events. }\end{array}$} & Pretest & 60 & 1,23 & 0,72 & \multirow{2}{*}{0,108} & \multirow{2}{*}{0,902} \\
\hline & Posttest & 60 & 1,27 & 0,64 & & \\
\hline \multirow{2}{*}{$\begin{array}{l}\text { I do not make any effort to be successful in Physical Education and } \\
\text { Sports course. }\end{array}$} & Pretest & 60 & 1,38 & 1,05 & \multirow{2}{*}{0,093} & \multirow{2}{*}{0,926} \\
\hline & Posttest & 60 & 1,37 & 0,82 & & \\
\hline \multirow{2}{*}{$\begin{array}{l}\text { I participate in Physical education and sports course because it is } \\
\text { compulsory as other courses. }\end{array}$} & Pretest & 60 & 1,62 & 1,23 & \multirow{2}{*}{$-0,542$} & \multirow{2}{*}{0,590} \\
\hline & Posttest & 60 & 1,74 & 1,40 & & \\
\hline \multirow[t]{2}{*}{ Talking about Physical Education and Sports is pleasurable. } & Pretest & 60 & 4,23 & 1,38 & \multirow{2}{*}{$-1,056$} & \multirow{2}{*}{0,295} \\
\hline & Posttest & 60 & 4,47 & 1,10 & & \\
\hline \multirow{2}{*}{$\begin{array}{l}\text { Since I very much enjoy Physical Education and Sports, I look forward } \\
\text { to the class. }\end{array}$} & Pretest & 60 & 4,16 & 1,45 & \multirow{2}{*}{$-1,967$} & \multirow{2}{*}{0,054} \\
\hline & Posttest & 60 & 4,56 & 0,87 & & \\
\hline I refrain from coming to the forefront in Physical Education and Sports & Pretest & 60 & 1,62 & 1,15 & -1131 & 0263 \\
\hline class. & Posttest & 60 & 1,86 & 1,22 & $-1,151$ & 0,200 \\
\hline My sense of cooperation develops in Physical Education and Sports & Pretest & 60 & 4,13 & 1,34 & -1082 & 0284 \\
\hline class. & Posttest & 60 & 4,36 & 1,07 & $-1,002$ & 0,204 \\
\hline Physical Education and Sports class teaches to be healthy and clean. & Pretest & 60 & 4,06 & 1,46 & & 0108 \\
\hline & Posttest & 60 & 4,47 & 1,10 & & 0,108 \\
\hline I do not want to take Physical Education and Sports class in my future & Pretest & 60 & 1,86 & 1,50 & 0.258 & 0.797 \\
\hline student life. & Posttest & 60 & 1,79 & 1,38 & & \\
\hline I believe that Physical Education and Sports activities contribute to the & Pretest & 60 & 4,42 & 1,22 & -0882 & 0381 \\
\hline healthy development of people. & Posttest & 60 & 4,59 & 0,89 & & 0,581 \\
\hline It is not necessary to include Physical Education and Sports class in & Pretest & 60 & 1,72 & 1,42 & 1418 & 0162 \\
\hline school curriculum. & Posttest & 60 & 1,41 & 0,97 & 1,410 & 0,102 \\
\hline I believe that the pursuit of Physical Education and Sports will bring & Pretest & 60 & 4,32 & 1,23 & 0124 & 0889 \\
\hline significant & Posttest & 60 & 4,42 & 1,07 & & 0,009 \\
\hline Every year of school curriculum should contain Physical Education and & Pretest & 60 & 4,25 & 1,42 & & \\
\hline Sports class. & Posttest & 60 & 4,47 & 1,11 & & 0 \\
\hline Participation in Physical Education and Sports activities rests me. & Pretest & 60 & 4,05 & 1,50 & -0.064 & 0.949 \\
\hline & Posttest & 60 & 4,06 & 1,42 & & \\
\hline I believe that the activities related to Physical Education and Sports & Pretest & 60 & 3,84 & 1,44 & -0882 & 0.415 \\
\hline gain honesty and democratic life behaviors. & Posttest & 60 & 4,05 & 1,33 & & 0,415 \\
\hline I believe that free time is better made use of by exercising and sporting. & Pretest & 60 & 4,10 & 1,59 & -2249 & $0028 *$ \\
\hline & Posttest & 60 & 4,60 & 0,96 & $-2,24 y$ & $0,0<0^{\circ}$ \\
\hline I believe that engaging in Physical Education and Sports events is a & Pretest & 60 & 1,85 & 1,54 & 56 & 3 \\
\hline waste of & Posttest & 60 & 1,46 & 1,06 & & 3 \\
\hline I do not feel like doing exercise and sports during my free time. & Pretest & 60 & 1,87 & 1,43 & 1,111 & 0,271 \\
\hline & Posttest & 60 & 1,62 & 1,05 & & \\
\hline I dedicate a significant amount of time for Physical Education and & Pretest & 60 & 3,75 & 1,62 & -0.262 & 0.794 \\
\hline Sport activities. & Posttest & 60 & 3,81 & 1,37 & $-0,202$ & \\
\hline I have no interest in anything related to Physical Education and Sports. & Pretest & 60 & 1,76 & 1,47 & 2021 & $0048 *$ \\
\hline & Posttest & 60 & 1,33 & 0,82 & & \\
\hline Physical Education and Sports activities always attracts my interest. & Pretest & 60 & 4,30 & 1,42 & 150 & 0.881 \\
\hline & Posttest & 60 & 4,27 & 1,17 & & 0,001 \\
\hline I do not recommend other people to participate in Physical Education & Pretest & 60 & 1,68 & 1,35 & & \\
\hline and $S p$ & Posttest & 60 & 1,45 & 0,98 & 053 & 0,500 \\
\hline
\end{tabular}

When Table 6, which indicates the opinions of the experimental group students, participating in the research, about their attitudes towards Physical Education and Sports Class, is examined, it is seen in result of the conducted dependent groups (related groups) $t$ test that there is significant difference at $p<.05$ level only in items 1,18 and 22 . As for other items, no significant difference in them was found in result of the related groups $t$ test.

When Table 6 is examined, it is seen, in result of the analysis conducted according to the test time variable of the experimental group students participating in the research, that there is significant difference $(p<.05)$ in the opinion item 
1 "In Physical Education and Sports classes, I always feel a sense of fear". While the students expressed, at the pretest, their opinion about this opinion item at the level of "I totally do not agree" $(\bar{X}=1,32)$ although it was close to "I do not agree, at the posttest it was at the level of "I totally do not agree" $(\bar{X}=1,08)$. According to these results, it can be said that the students of the experimental group adopt the opinion "In Physical Education and Sports classes, I always feel a sense of fear" less in the posttest than in the pretest. According to this result, it is observed that by means of physical activity cards the students' levels of feeling a sense of fear of participating in physical education classes decrease.

When Table 6 is examined, it is seen, in result of the analysis conducted according to the test time variable of the experimental group students participating in the research, that there is significant difference $(p<.05)$ in the opinion item 18 "I believe that free time is better made use of by exercising and sporting". While the students expressed, at the pretest, their opinion about this opinion item at the level of "I agree" $(\bar{X}=4,10)$, at the posttest it was at the level of "I totally agree" $(\bar{X}=4,60)$. According to these results, it can be said that the students of the experimental group adopt the opinion "I believe that free time is better made use of by exercising and sporting" less in the posttest than in the pretest.

When Table 6 is examined, it is seen, in result of the analysis conducted according to the test time variable of the experimental group students participating in the research, that there is significant difference $(p<.05)$ in the opinion item 1 "I have no interest in anything related to Physical Education and Sports". While the students expressed, at the pretest, their opinion about this opinion item at the level of "I totally do not agree" $(\bar{X}=1,76)$ although it was close to "I do not agree, at the posttest it was at the level of "I totally do not agree" $(\bar{X}=1,33)$. According to these results, it can be said that the students of the experimental group adopt the opinion "I have no interest in anything related to Physical Education and Sports" more in the posttest than in the pretest.

\section{Discussion and Conclusion}

In this research, the effects of the peer tutoring method in the courses, conducted by applying peer evaluation method, on attitudes of the students, attending secondary school, towards the course of physical education and sports. As a result of the research, it was determined that while student's academic successes were higher in peer tutoring method compared to the traditional education method, their attitudes towards the course of physical education and sports were positively affected.

Teachers act only as observer and guide while the peer tutoring method is applied. Students explain basic skills and concepts included in the curriculum to each other, discuss problems; students learn themselves too, while they teach their peers. Our peer tutoring method was conducted in a way similar to the works by Podolner (2000), Crouch and Mazur (2001), Topping (2005), Can (2009), Yardım (2009), Yavuz (2014), Yeşiloğlu (2015), Dölek 2016), Yaşar (2016), and Özcan (2016), which are in the literature.

In the result of the application of the method, while performance increase was observed in the students, it was determined that class skills of the students developed, the students learned themselves too, while they taught, the students, who had little interest in the class, were led to participate in the class and success in the class increased, the students with much interest in the class learned more by having a good time. It was observed these findings of our research matched up with the works, included in the literature, by Mazur (1997), Crouch and Mazur (2001), Yavuz (2014), Yeşiloğlu (2015), Dölek (2016), Yaşar (2016), Özcan (2016), Eryılmaz 2004), Tokgöz (2007), and Demirci and Şekercioğlu (2009).

It was determined in result of the research that the students were trying to be patient and more explanatory while they taught skills to their friends, and that in the evaluation, they gave their friends fair and high grades and made positive comments and constructive criticisms. These findings are in parallel with the findings in the works, included in the literature, by Demirci and Yavuz (2009), Yeşiloğlu (2015), Dölek (2016), Yaşar (2016), Özcan (2016), Şekercioğlu (2009), Gülçek (2015), Mazlum (2015), Çelik (2015), Güvey Aktay (2015), Cebeci (2015) and Biri (2015).

The students generally considered positively the use of physical activity cards and peer education in physical education class. It was determined that, because the students overcame the tiring effect of the current education system through the physical education classes, they developed positive attitudes towards the physical education classes both before and after the application. It was determined in result of the conducted analyses that they were effective in terms of the participation in the class by the students, who did not like the application course and were not active in the class. Furthermore, it was an effective method in leading the passive students, who could not participate in the class due to lack of self-confidence, to actively participate in the class. Besides, another positive aspect of the method is that it is not affected by high population of the classroom. The participation of the students in the classes both individually and in groups develops positive loyalty in one hand and facilitates controlling of the class on the other hand. 
Transfer of knowledge by the students to their friends through the peer education also develops both cooperation and socialization between students. When we examine the effect of the application with regard to gender, we observe that it is included among the findings of the research that the female students more increased their attitudes towards physical education classes. The high level of attitudes by male students towards physical education courses did not cause much difference in the attitude increase. Also, when we look at the effect of the application in terms of the test time, it was determined that it positively affected the student attitudes, and that this increase was not at high level. The reason for this may be that the students had positive attitudes towards the physical education courses before the application as well.

\section{References}

Açak, M. (2005). Guidebook of Physical Education Teacher, İstanbul: Yayc1lık Printing House,

Aybek, A. (2007). The Role of Physical Education Teachers in the Attitudes of Students Towards Physical Education Class and Extracurricular Activities. Master's Thesis. Samsun: May 19 University.

Bir, H. (2015). Contribution of the Peer Assessment Method to Teacher Education, Master's Thesis, Trabzon: Karadeniz Technical University, Institute of Educational Sciences.

Can, Ü. K. (2009). Testing the Effectiveness of Peer Instruction Program Developed for Music Teaching Guitar Students, Doctoral Thesis, Istanbul: Marmara University Institute of Educational Sciences.

Cebeci, S. (2015). The Effect of Peer-Supported Education in Pre-Graduate Medical Education on Students' Success in Theoretical Courses, Ankara: Hacettepe University, Institute of Health Sciences.

Çelik, E. (2015). Use of Peer Assessment Method in Public Courses Via Internet: A Case Study, Doctoral Thesis, Erzurum: Atatürk University, Institute of Educational Sciences.

Çolakoğlu, T. (2004). School Sports in Terms of Popularizing Sports. Doctoral Thesis. Ankara: Gazi University.

Crouch, C. H., \& Mazur, E. (2001). Peer instruction: Ten years of experience and results. American Journal of Physics, 69(9), 970-977. https://doi.org/10.1119/1.1374249

Demirci, N., \& Şekercioğlu, A. G. (2009). The Effect of the Peer Instruction Method on, and its Orientation to, University Students' Success on Electrostatics. eJournal of New World Sciences Academy (NWSA), 4(1), 37-51.

Dölek, O. (2016). The Effect of the Writing Activities Based on Peer Interaction on Written Expression Skills of $7^{\text {th }}$ Grade Students, Master's Thesis, Gaziantep: Gaziantep University, Institute of Educational Sciences.

Dudley, D. A., Okely, A. D., Cotton, W. G., Pearson, P., \& Caputi, P. (2012). Physical activity levels and movement skill instruction in secondary school physical education. Journal of Science and Medicine in Sport, 15, 231-237. https://doi.org/10.1016/j.jsams.2011.10.005

Eryllmaz, H. (2004). The Effect of Peer Instruction on High School Students' Achievement and Attitudes Toward Physics (Doctoral Dissertation), Doctoral Thesis, Ankara: Middle East Technical University, Institute of Science.

Gülçek, N. (2015). The Effect of the Peer Instruction on the Science Success of Teacher Candidates on Ideal Gases, Master's Thesis, Malatya: Inonu University, Institute of Educational Sciences.

Güvey, A. E. (2015). Peer Cooperation in First Literacy Teaching, Doctoral Thesis, Eskişehir: Anadolu University, Institute of Educational Sciences.

İnal, A. N. (2003). Physical Education and Sports Science. Ankara: Nobel Publication Distribution.

Kangalgil, M., \& Dönmez, B. (2003). Opinions of Primary School Teachers about Physical Education Class (Example of Sivas), Journal of National Education 159. 20-24.

Mazlum, E. (2015). Examination of Concept Information Indicators About Light through Peer Instruction Applications, Master's Thesis, Trabzon: Karadeniz Technical University, Institute of Educational Sciences.

Mazur, E. (1997). Peer instruction: A user's manual. New York: Prentice Hall.

Ministry of Education, General Directorate of Basic Education, Game and Physical Activities Course Curriculum, TTKB Decision No. 75, http://tegm.meb.gov.tr/www/oyun-ve-fiziki-etkinlikler-dersi-ogretim-programi/icerik/62 accessed on October18, 2015.

Ministry of Education, General Directorate of Basic Education, Physical Education and Sports Course Curriculum, TTKB Decision No. 56, http://ttkb.meb.gov.tr/dosyalar/programlar/ilkogretim/ortaokul_bedenegitimi.pdf accessed on October18, 2015.

Mynard, J., \& Almarzouqi, I. (2006). Investigating peer instruction. Elt Journal, 60(1), 13-22. 
https://doi.org/10.1093/elt/cci077

Ozcan, O. (2016). Teaching the subject of Acids and Bases in $12^{\text {th }}$ Grades Through Peer Instruction Method: An Action Research, Doctoral Thesis, Erzurum: Atatürk University, Institute of Educational Sciences.

Podolner, A. S. (2000). Eradicating physics misconceptions using the conceptual change method (Doctoral dissertation).

Tokgöz, S. S. (2007). Effect of Peer Instruction on Sixth Grade Students' Success in, and Attitudes Towards, the Science Course, Doctoral Thesis, Ankara: Middle East Technical University, Institute of Science.

Topping, K. J. (2005). Trends in peer learning. Educational Psychology, 25(6), 631-645. https://doi.org/10.1080/01443410500345172

Yardım, H. G. (2009). Action Research on the Effect of the Peer Education Approach in Mathematics Courses on $9^{\text {th }}$ Grade Students, Master's Thesis, Gazi University, Institute of Educational Sciences, Ankara.

Yaşar, A. (2016). The Effect of Peer Instruction Method on Secondary School Students' Conceptual Understanding of, and Attitudes Towards, the subjects of Electricity and Magnetism, Master's Thesis, Balikesir: Balıkesir University, Institute of Science.

Yavuz, O. C. (2014). The Effect of the Peer Instruction, which is Enriched with WEB Based Peer and Self-Assessment System, on the Success and Attitudes of Students with Regard To $7^{\text {th }}$ Grade Rational Numbers, Doctoral Thesis, Sakarya: Dumlupınar University, Institute of Educational Sciences.

Yeşiloğlu, Ö. (2015). The Effect of the Peer Instruction Method on Teaching of the High School Level Electricity-Related Concepts, Doctoral Thesis, Erzurum: Atatürk University, Institute of Educational Sciences.

Zhu, E. (2007). Teaching with clickers. Center for Research on Learning and Teaching Occasional Papers.

\section{Copyrights}

Copyright for this article is retained by the author(s), with first publication rights granted to the journal.

This is an open-access article distributed under the terms and conditions of the Creative Commons Attribution license which permits unrestricted use, distribution, and reproduction in any medium, provided the original work is properly cited. 